\title{
Examining the Relationship Among Bullying, School Climate and Adolescent Well-Being in Chile and South Africa: a Cross Cultural Comparison
}

\author{
Jorge J. Varela ${ }^{1} \&$ Shazly Savahl2 2 Sabirah Adams ${ }^{2}$ \& Fernando Reyes ${ }^{3}$ \\ ${ }^{1}$ Facultad de Psicología, Universidad del Desarrollo, Av. Plaza, 680 Santiago, Chile \\ ${ }^{2}$ Department of Psychology, Faculty of Community and Health, University of the Western Cape, \\ Cape Town, South Africa \\ ${ }^{3}$ Facultad de Psicología, Universidad del Desarollo, Ainavillo 456, Concepción, Chile
}

\begin{abstract}
Bullying at school represents a major challenge in different school cultural contexts. As a result, victims of bullying experience negative consequences that influence their daily life and personal well-being. School climate in particular is important to consider in the prevention of bullying and its consequences. However, few studies have examined the effects of bullying victimization on children's subjective well-being (SWB), using hierarchical analysis, in different cultural contexts. Therefore, the current study examined the role of bullying victimization and school climate on children's SWB in two different contexts, Chile and South Africa. The study forms part of and uses data from the Children's Worlds Study in these contexts. With a combined sample of 1829 children aged 12-years old, the data were analyzed using hierarchical linear modeling and structural equation modeling. The key findings indicate that bullying victimization was a significant predictor of children's SWB at the individual and school level (school climate) in Chile and South Africa. Further, a crosslevel interaction effect of school climate on the relationship between bullying victimization and SWB was found in Chile only. Mediational analysis demonstrated a good fit of the data for both countries, and indicated that bullying victimization had a direct effect on SWB, and an indirect effect through school climate. These results contribute to a better understanding of the role of school climate for bullying behavior, especially for victims. Schools represent an important institution, beyond the cultural context, that can help foster children's social development by promoting a positive school climate.
\end{abstract}

Keyword: subjective well-being, bullying, school climate, Chile, South Africa

\section{Introduction}

The focus on the social and relational aspects of children and youth's lives have been identified as critical domains of their subjective well-being (SWB). It is therefore important to consider different predictors of children and youth's SWB, particularly within the school 
context (Eccles and Roeser 2010), such as school climate and negative experiences of bullying behavior. The emphasis on school climate is especially apposite given the recent work of Casas and González (2017) proposing the 'two worlds hypothesis', based on evidence that children conceptualise school comprising two domains. The first domain focuses on 'learning, teachers, and achievement', and the second on 'peers and friendships' (Casas and González 2017). Although there is substantial research on children's SWB, there is less research examining the importance of different school variables that influence SWB (Huebner et al. 2014). Moreover, research on the topic has focused on developed countries and provides meaningful information to better understand the bullying phenomenon. However, research from different cultural contexts is needed to provide a more comprehensive understanding. Therefore, the aim of the present paper is to examine whether school climate provides an explanation for the relationship between bullying victimisation and adolescent well-being in two different cultural contexts, namely Chile and South Africa.

\section{Subjective Well-Being}

There has been increased interest in SWB as an academic discipline in the last three decades (Diener et al. 1999; Diener 2012), and the exploration and identification of the predictors thereof. Subjective well-being can be defined as a personal evaluation people make about their lives and overall quality of life, and comprises three components: life satisfaction, positive affect, and negative affect. This evaluation can be made in terms of different personal domains such as life as a whole, to more specific areas like friends, school, family, and the community (Huebner 2004). Adolescent's SWB, in particular, can be examined by considering individual and contextual aspects (Casas 2011).

Various predictors of adolescent's SWB have been identified (Ben-Arieh et al. 2001; Bradshaw and Mayhew 2005; Shek and Liang 2018), considering the neighbourhood (Elvas and Moniz 2010; Fattore et al. 2012), and family (Goswami 2013; Rees et al. 2012). While these are important contexts for their development, peers and school have emerged as important for adolescent well-being (Casas and González 2017). Previous studies have reported a positive relationship between life satisfaction and school satisfaction (Casas and Bello 2012; Oyanedel et al. 2014; Samdal et al. 2004; Sarriera et al. 2014). More specifically, school climate has been found to be positively related to life satisfaction (Currie et al. 2004; Jutras and Lepage 2006; Suldo et al. 2008) and school satisfaction (Ito and Smith 2006; Zullig et al. 2018). Previous studies have thus highlighted the importance of the school for children's well-being (Alfaro et al. 2016), and more importantly meaningful relationships with their peers (Huebner et al. 2004). Within the school context, becoming a victim of bullying behavior has become an important risk factors for children's SWB (Turner et al. 2014), general adjustment (Felix et al. 2009), and life satisfaction (MacDonald et al. 2005; Martin and Huebner 2007; Proctor et al. 2009; Valois et al. 2006). The significance of the relationship between SWB and objective indicators has also been underscored (Bradshaw et al. 2013), and points to the importance of country and cultural comparisons to explain differences across various SWB measures (Dinisman and Ben-Arieh 2015; Newland et al. 2019). However, there is a dearth of research focusing on the negative consequences of 
objective and subjective domains of children's well-being using multilevel methods to account for differences between school experiences.

\section{Bullying Victimisation}

Bullying at school has been put under scientific scrutiny by Olweus (see Olweus 1978; Olweus and Breivik 2014) and has received a focused increased among researchers since (Craig et al. 2009). More than four decades later, all the deleterious effects of and the evolving nature of bullying in different cultural contexts have not been fully explored. While a wealth of literature focuses on bullying, few studies have investigated the associations with SWB from an ecological perspective; combining the individual, interpersonal, contextual, and social factors that contribute to this phenomenon. Fewer studies have been conducted that considers the subjective perspectives of children and adolescents as key informers of their lives, providing their perceptions, evaluations and satisfactions, based on studies focused on quality of life (Casas et al. 2013).

As demonstrated in contemporary literature, the incidence of bullying is dependent on the methodologies used to measure it, and contextual factors such as age, gender and sociocultural context (Espelage and De La Rue 2012). Research shows that South Africa has among the highest prevalence of violence and violence-related injury in the world (Norman et al. 2010). While violence transcends boundaries of class and socioeconomic status, impoverished communities display higher levels of various forms of violence (Savahl et al. 2015, 2017). Investigations into child violence have proliferated owing to the importance assigned to children's rights in the Constitution, the African Charter on the Rights and Welfare of the Child, and the United Nations Convention on the Rights of the Child. Of the various forms of violence that children face, bullying, along with sexual violence and corporal punishment, has become a common occurrence within the school setting (Mathews and Benvenuti 2014). In particular, results from Wave 2 of the Children's Worlds Study demonstrated that out of 15 countries, South Africa had the highest rates of bullying victimization, in terms of 'being hit' and 'left out' by other children in their schools (Rees and Main 2015). Within the literature of school-based bullying, it is clear that bullying transcends cultural and geographical boundaries (Craig et al. 2009). However, there is noticeable dearth of cross-national studies. The cross-cultural comparative study by Savahl et al. (2018) explored children's experiences of bullying victimization (physical and psychological) and SWB across three age groups $(8,10$ \& 12) and 15 geographical regions, including South Africa. The study results demonstrated appropriate fit structure for the overall model, as well as the significant combined influence of physical and psychological bullying on children's SWB across age groups and geographical regions. Richardson and Hiu (2016) reviewed global data on school-based bullying and identified six cross national surveys, of which the Children's Worlds Study is one.

Over the last few decades in Chile, there has been a growing interest by researchers

from different disciplines in the study of different types of violence in school (e.g., Human ethology: Muñoz-Reyes et al. 2016; Psychology: Berger 2012; Varela 2011; Education: Magendzo et al. 2012). Similarly, private and governmental organizations have conducted long-range studies to gain an in-depth understanding of the extent of bullying. For example, 
a national study conducted in 2014 showed that $22.3 \%$ of students indicated that they were physically attacked by other students in the school context, compared to $24.1 \%$ who indicated that they attacked other students during the same period in school (Ministerio del Interior 2014). Moreover, a nationwide survey by the Ministry of Education reported that $14.5 \%$ of students in the country were victims of threats or permanent harassment, and discrimination by another student in the school context (Ministerio de Educación 2011). Most of the victims of aggression were males between 10 and 14 years old (Ministerio del Interior and Adimark GFK 2010; Ministerio del Interior 2014). In addition, psychological violence was found to be the most prevalent among the victims (Ministerio del Interior and Adimark GFK 2008, 2010). More so, $87.8 \%$ of Chilean students in the seventh grade (12 years) and $12^{\text {th }}$ grade (17 years), were victims of cyberbullying via the internet or via a cellular phone (Varela et al. 2012). Finally, the most recent data in Chile presents alarming results from a national survey among students in Chilean schools. It was found that $61 \%$ of the students told that they were a victim of bullying, whereas $84 \%$ of the students indicated that they witnessed some kind of bullying in their school (within the school year) (Instituto Nacional de la Juventud 2017).

Recent studies highlight the negative consequences of bullying for victims and wellbeing (Menesini and Salmivalli 2017; Varela et al. 2017). This negative association has been found in different cultural contexts. For example in Algeria, Tiliouine (2015) found a negative association between passive bullying, being excluded by peers, and life satisfaction as a whole in a sample of 1452 school-going children. Previous studies have compared several countries to examine bullying behavior (Craig et al. 2009), the association with mental health (Due et al. 2005), income inequality and school bullying (Elgar et al. 2009), or trend comparisons between Europe and North America (Molcho et al. 2009). Notwithstanding, less is known about other cultural contexts in developing contexts that share a history of colonization and violence at some point in their history, such as Chile and South Africa.

A particular area of research that has gained momentum in recent years, is the relationship between school climate (quality and experience of school life) and bullying victimization; with structured and positive school climates related to lower reported incidences of bullying (Wang et al. 2013). Within the literature of school-based bullying, it is clear that bullying transcends cultural and geographical boundaries. However, there is a noticeable dearth of cross-national studies. The current study hopes to contribute in this regard by using similar validated measures of children's SWB and bullying victimization in different cultural contexts.

\section{School Climate}

Human development occurs at multiple levels and has a reciprocal influence, especially from the school context during adolescence (Eccles and Roeser 2010; Lerner 2006).Within the school context there are different dimensions relevant for adolescent wellbeing development, such as peer relationships and school climate. School climate is a multidimensional construct that can be described as the prevailing atmosphere in an academic institution that sets the norms, values, rules, and structures of a school as a whole (Cohen et al. 2009; Gage et al. 2014; Rudasill et al. 2018). 
It is evident that various features from the school environment play an important role in adolescent's well-being development. In this regard, adolescents who reported having a close relationship with their school were less likely to engage in different types of risk behaviors (McNeely and Falci 2004). It has been found that a negative attitude about school can contribute to the risk for violence (Henry et al. 2012). Further, a positive relationship and attachment to school has also been associated with lower levels of aggressive beliefs (Frey et al. 2009), while a negative relationship has been found between school bonding and problem behavior (Catalano et al. 2004; Fleming et al. 2010). The school climate therefore contributes to supporting and enhancing student's well-being. The results from the Programme for International Student Assessment (PISA) in 2015 highlighted the significant role of the teacher-student relationship for student well-being (OECD 2017).

School climate is an important feature of the school culture that varies across countries. Previous studies have found differences in the perception of school climate in different countries. Yang et al. (2013) compared a sample of 10,400 American and 3435 Chinese students, across middle and high school, with Chinese students demonstrating higher positive perceptions of their school climate. Pizmony-Levy and Kosciw (2016) found differences in the perceptions of school climate among adolescent sexual minorities in the United States of America (USA) and Israel. While victimization was evident in both countries', adolescents from the USAwere more likely to be a victim of being called unkind or negative remarks.

\subsection{Aim of the Study}

Research on school climate has contributed to unpacking the various aspects that influence children's well-being (e.g. Kutsyuruba et al. 2015; Låftman et al. 2017). However, the current study hopes to contribute to the literature by focusing on adolescents from different cultural contexts using multilevel modeling. The study uses data from the Wave One of the Children's Worlds Study (see www.iscweb.org), and aims to explore the relationship between bullying victimization and school climate on adolescent's SWB, with a cross-national sample of children from Chile and South Africa. More specifically the study aims to ascertain the extent to which school climate mediates the relationship between bullying victimization and SWB.

\section{Methods}

\subsection{Research Design}

The study uses data from Wave One (Deep Pilot) of the Children's Worlds Study, an international comparative survey of children's lives and well-being, and follows a crosssectional design. The survey instrument for the Children's Worlds Study was developed in English and Spanish. The survey was adapted to each respective country context. In South Africa, the survey was also translated and adapted to Afrikaans, using the back-translation method, given that it is one of the most widely spoken languages in the region. 


\subsubsection{School System in South Africa}

Education is a national priority and prominent feature on the children's rights agenda in South Africa (United Nations Children's Fund [UNICEF] 2013). The basic education system comprised of 12,892, 273 learners, 25,762 schools and 433,320 teachers in 2017 (Department of Basic Education DBE 2018) across public ordinary and independent (private) schools. The school life spans over 13 grades from grade $0-12$, of which the majority of South African children enrolled are at the primary school level (DBE 2018). The national average learner to educator (LER) proportion was 31.3 to 1, nationally (DBE 2018). Over the past few years, there have been no major improvements in both national and provincial LER.

\subsubsection{School System in Chile}

The right to education and free access to education in Chile are enshrined in the Political Constitution of the country. Education in Chile is divided into four levels: nursery, basic, middle, and higher; with basic education comprising 8 years, and 4 years of secondary education, both regulated by the Ministry of Education (MINEDUC 2017). According to the Ministry, the education system had a total of 3,550,837 (56\% Basic Education; and 44\% Secondary Education) students, across 11,858 educational establishments (70\% urban; and $30 \%$ rural) with 230,142 teachers. These educational establishments are divided into Public (44\%), Semi Public (50\%), Private (5\%) and delegated administration Corporations (1\%) (MINEDUC 2017). Expenditure on education in Chile reaches $6.1 \%$ of gross domestic product (GDP), of which $3.6 \%$ is allocated to primary and secondary education, and $2.5 \%$ toward higher education; which is below the average of $5.3 \%$ for OECD countries (OECD 2015).

\subsection{Sampling}

The sampling frame for the current study included 12-year olds participating in Wave One of the Children'sWorlds Study in Chile and South Africa. The sample comprised a total of 1829 children in grade seven. The sample from Chile included 827 students (42.2\% female) from 39 schools in Chile, and a sample of 1002 students (53.9\% female) from 15 schools in South Africa.

The sample from South Africa included participants attending primary schools located in low and middle socio-economic status (SES) communities within the Western Cape Metropole region. While the international research study targeted 1000 children in each of three age groups $(8,10,12)$ for participating countries, it does make provision for deviation from this protocol. Given resource constraints an exploratory design was followed in the South African study and was limited to the 12-year old age cohort. A total of 1048 children from South Africa participated in the study. Once the data were cleaned, and damaged and incomplete questionnaires discarded, the final sample consisted of 1004 participants. The sample included $58.6 \%$ of children attending schools in low SES communities and $41.4 \%$ from middle SES schools. Girls comprised $53.9 \%$ of the sample, while boys comprised $46.1 \%$ of the sample. The participants were selected using stratified random sampling to ensure that 
children from various cultural, income, and status groups are selected. Schools were stratified according to their location within specific Education Management District Councils (EMDC's), namely Metro North, Metro East, Metro Central, and Metro South. Thereafter, schools were randomly selected within each of these EMDC's using the socioeconomic status (low and middle) and income level as defining variables. The final sample consisted of eight schools from low SES and seven from middle SES communities.

In Chile, the sampling procedure followed the Children'sWorlds Study international guidelines. Data were collected during the 2012 school year. The sample included children in grades three, five, and seventh enrolled in educational establishments in the urban areas of the Metropolitan (XII), Valparaíso (V), and Biobío regions (VIII). These three regions represent $62.4 \%$ of the national population. The total sample in Chile was 2572 cases, with a maximum total error of $\pm 1.9 \%$ and a $95 \%$ level of confidence (assuming maximum variance). The maximum error per course is $\pm 3.5 \%$ for a $95 \%$ confidence level (also, assuming maximum variance).

\subsection{Data Collection}

Data were collected through the administration of the Children's Worlds standardized survey to the participants in their respective classrooms per grade within the selected schools. Research ethics procedures and guidelines, as outlined by the universities that the authors are based at, as well as the education ministries were strictly adhered to during the survey administration, such as confidentiality, informed consent, and the right to withdraw from the study without consequences, within both countries.

\subsection{Measures}

\subsubsection{Brief Multidimensional Students' Life Satisfaction Scale (BMSLSS)}

In the study, SWB was measured using the Brief Multidimensional Students' Life Satisfaction Scale (BMSLSS) (Seligson et al. 2003). The BMSLSS examines children and adolescents subjective perceptions about various domains of their well-being, namely family, friends, school, and life in general. The measure employs an 11-point Likert scale (o = strongly unsatisfactory, $10=$ strong satisfactory). A higher overall score indicates a more positive evaluation of their life satisfaction, with lower scores indicating a lower level of life satisfaction across the various domains. Examples of item are: "How satisfied are you with each of the following things in your life: "Your friends?", "Your school experience?", "Yourself?". The scale has demonstrated acceptable internal consistency using Cronbach's alpha ( $\alpha$ ) across various contexts: In Algeria, the $\alpha$ ranged from .53 (10-years olds) to .66 (12 year olds) (Tiliouine 2015); in Italy (Migliorini et al. 2019) $\alpha=.64$ (8-year olds); in Brazil $\alpha=$ .69 with 9-13 year olds (Schütz et al. 2018); in Poland with children aged 8, 10, and 12-year olds, $\alpha$ ranged from 0.64 to 0.76 (Strozik et al. 2016); in India $\alpha=0.82$ with adolescents ( $x$ age $=16.05$ years) (Hashim and Areepattamannil 2017); a longitudinal study with adolescents in the USA, found that at Time $1, \alpha=.79$ and at Time $2, \alpha=.83$ ( $\mathrm{Ng}$ et al. 2017); in Canada with a sample of youth (11-17 years old) with chronic health conditions $\alpha=0.73$, and parent 
report versions $\alpha=0.81$ (McDougall et al. 2013), and finally cross-country comparative studies demonstrate acceptable reliability coefficients: $\alpha=.618$ across Spain, South Africa, Algeria, and Israel (Gonzalez-Carrasco et al. 2018), and ranging from .69 to .94 across 23 countries (Abubakr et al. 2016).

\subsubsection{Bullying Victimization}

Bullying victimization was assessed using two items from the Children's Worlds Study survey that examined the frequency of self-reported aggressions from peers in the school during the last month. These items asked adolescents about the frequency of physical ("How often, it at all, in the last month have you been... hit by other children in your school") and relational aggression ("How often, it at all, in the last month have you been left out by other children in your class"). The items are scored on a 4-point Likert scale ( $0=$ Never; $1=$ Once); $2=2-3$ times; and $3=$ More than 3 times), with higher scores indicating a higher frequency of bullying victimisation. These items have been used in previous studies forming part of the Children's Worlds Study (see Tiliouine 2015; Savahl et al. 2018).

\subsubsection{School Climate}

School climate was measured using four items that examined different features of school life to contribute a better climate. The items are scored on a five-point Likert scale ( $0=$ Strongly disagree; 1 = Disagree; 2 = Neither disagree nor agree; $3=$ Agree; $4=$ Strongly agree) . Examples of items include: "How much do you agree or disagree with each of these sentences: My teachers listen to me and take what I say into account"; "I like going to school"; "I feel safe at school". A higher score indicates a higher self-reported assessment of a positive school climate.

\subsubsection{Demographic Variables}

Gender was used in the models as a control variable dummy coded ( $1=$ male; $2=$ female). Age was controlled by using data only from the 12-year olds dataset from Children's Worlds Study.

\subsection{Data Analysis}

Hierarchical Linear Modeling (HLM) was used due the nested structure of the data. To examine the multilevel influence of bullying victimization a multilevel analysis approach (Hierarchical Linear Modeling) was employed to examine the multi-level influences on adolescent's SWB (Raudenbush and Bryk 2002). Multilevel analysis was appropriate for the current study as it allows for the partitioning of the within school and between-school variance for the outcome variable, and therefore takes into account differences between schools and their relationship with different SWB domains. We used Structural Equation Modeling (SEM) to examine mediation among the study variables. 


\section{Results}

Descriptive statistics are described in Tables 1 and 2 for Chile and South Africa. Tables 3 and 4 report the correlations among the study variables for Chile and South Africa. Males reported higher bullying victimization in the Chilean sample, and female higher levels of school climate perception for the South African sample. In both countries bullying victimization was negatively related to school climate and the BMSLSS. Lastly, school climate and BMSLSS were positively related in both countries.

The hierarchical analysis results demonstrate that in Chile and South Africa bullying victimization, at the individual level $\left(\beta_{3}=-.31, \mathrm{p}<.01 / \beta_{3}=-.49, \mathrm{p}<.01\right)$, and school climate $(\gamma 01=.27, \mathrm{p}<.01 \gamma 01=.13, \mathrm{p}<.06)$, at the school level, were significant predictors of BMSLSS (see Tables 5 and 6). In addition, a cross-level interaction effect of school climate on the relationship between bullying victimization and BMSLSS was found for Chile only $(\gamma 21=.10, \mathrm{p}<.05 ; \gamma 21=.10, \mathrm{p}<.24)$ (Fig. 1).

The mediational analysis demonstrated a good fit of the data for both countries (Chile: $\chi_{2}[66, \mathrm{~N}=827]=1763.83, \mathrm{p}<.001$, with TLI $=0.90, \mathrm{CFI}=0.93, \mathrm{RMSEA}=0.06$. South Africa: $\chi 2[66, \mathrm{~N}=1002]=1310.61, \mathrm{p}<.001$, with TLI $=0.91, \mathrm{CFI}=0.93$, RMSEA $=0.04$ ). These results are reported in Table 7, Table 8, and Fig. 2. All paths were significant for Chile and South Africa: bullying victimization had a direct effect on BMLSS $(\beta=-.28, p<.01 ; \beta=$ $-.53, \mathrm{p}<.01)$, and indirect effect through school climate $(\beta=-.12, \mathrm{p}<.01 ; \beta=-.17, \mathrm{p}<.01)$. School climate was associated with BMSLSS $(\beta=.68, \mathrm{p}<.01 ; \beta=.41, \mathrm{p}<.01)$.

\section{Discussion}

The study aimed to explore the relationship between bullying victimization and school climate on adolescent's SWB, with a cross-national sample of children from Chile and South Africa. More specifically the study aims to ascertain the extent to which school climate mediates the relationship between bullying victimization and SWB. A key finding of the study was the negative relationship between bullying victimization and adolescent SWB in Chile and South Africa. Further, this relationship was mediated by school climate in both countries, and provides a complementary dimension to better understand well-being in both cultural contexts.

Table 1 Descriptive statistics Chile

\begin{tabular}{llllll}
\hline & M & SD & $\%$ & Minimum & Maximum \\
\hline Sex (Female) & - & - & 42,2 & 1 & 2 \\
Victimization & .40 & .66 & - & 0 & 3 \\
School Climate & 3.03 & .77 & - & 0 & 4 \\
BMSLSS & 8.34 & 1.51 & - & 0 & 10 \\
\hline
\end{tabular}


Table 2 Descriptive statistics South Africa

\begin{tabular}{lccccc}
\hline & M & SD & $\%$ & Minimum & Maximum \\
\hline Sex (Female) & - & - & 53,8 & 1 & 2 \\
Victimization & .79 & .87 & - & 0 & 3 \\
School Climate & 3.06 & .80 & - & 0 & 4 \\
BMSLSS & 8.37 & 1.47 & - & 0 & 10 \\
\hline
\end{tabular}

This study adds to the literature by highlighting the importance of school climate for children and adolescent's lives, particularly for victims of bullying behavior in the school context. Although previous research has found that victims are at higher risk for adjustment difficulties (Felix et al. 2009) and decreased life satisfaction (MacDonald et al. 2005; Martin and Huebner 2007; Proctor et al. 2009; Valois et al. 2006), our results highlight the importance of the school climate as a school feature that can provide additional support for these students. The results can also inform bullying prevention programs by including this as a key aspect that influences adolescent's school life.

Another key finding was that bullying was higher among males in Chile only. This finding aligns to several large-scale international comparative studies that have found a significantly higher rate of bullying among males across a range of countries (see Bradshaw and Rees 2017). As the literature shows a decreasing trend of bullying with age, it is recommended that future studies compare different age cohorts of children across countries. The study by Bradshaw and Rees (2017) compared children across three age groups (8, 10, and 12-years) across 15 countries using Wave One of the Children's Worlds Study and found this decrease. Interestingly, bullying victimization across the contexts (developed and developing countries) included varied, and did not appear to be related to national wealth.

Table 3 Correlations among study variables Chile

\begin{tabular}{lllll}
\hline & Sex (Female) & Victimization & School climate & BMSLSS \\
\hline Sex (Female) & - & & & \\
Victimzation & $-.07^{*}$ & - & \\
School Climate & .03 & $-.10^{* *}$ & - & \\
BMSLSS & -.06 & $-.19 * *$ & $.43^{* *}$ & - \\
\hline
\end{tabular}

$* * p<.01 ; * p<.05$ 


\begin{tabular}{lllll}
\hline & Sex (Female) & Victimization & School climate & BMSLSS \\
\hline Sex (Female) & - & & \\
Victimization & .05 & - & \\
School Climate & $.08 *$ & $-.18 * *$ & - & \\
BMSLSS & -.01 & $-.32 * *$ & $.32 * *$ & - \\
\hline
\end{tabular}

$* * p<.01 ; * p<.05$

Schools have the potential to support the well-being of adolescents and youth, in particular through a positive school climate (Aldridge and McChesney 2018). Moreover, positive school climates may decrease the likelihood of school-based bullying perpetration (Mehta et al. 2009; Klein et al. 2012). Schools with positive climate can also improve positive peer interactions, lessen peer rejection, and enhance both academic achievement and social development (Loukas and Murphy 2007). Social and emotional learning (SEL) programs that seek to foster students' resiliency, supportive relationships, responsibility, and reflection can consider school climate features to achieve their goals and to prevent the negative impact of violent behaviors on adolescent's and youth well-being (Bonell et al. 2018).

The focus on SWB and bullying vicitimization within the school climate in Chile and South Africa accentuates the importance of considering different contextual factors to better understanding this relationship.

Table 5 Resutls from the Between-school Model of BMSLSS for Chile

\begin{tabular}{|c|c|c|c|c|c|}
\hline Fixed effect & Coefficient & $S E$ & $t$ & $d f$ & $p$ \\
\hline \multicolumn{6}{|l|}{ School mean BMSLSS } \\
\hline Base, $\gamma_{00}$ & $8.33 * * *$ & 0.05 & 162.99 & 37 & 0.00 \\
\hline School climate, $\gamma_{0 I}$ & $0.27^{* * * *}$ & 0.06 & 4.69 & 37 & 0.00 \\
\hline \multicolumn{6}{|l|}{ Gender (Female) } \\
\hline Base, $\gamma_{I 0}$ & $-.22 *$ & .12 & -1.85 & 809 & 0.07 \\
\hline \multicolumn{6}{|l|}{ Victimization, } \\
\hline Base, $\gamma_{3201}$ & $-.31 * * *$ & .07 & -4.36 & 37 & 0.00 \\
\hline School Climate, $\gamma_{2 I}$ & $.10^{* *}$ & .05 & 2.05 & 37 & 0.05 \\
\hline Random effect & Variance component & $d f$ & $\chi^{2}$ & $p$ & \\
\hline Mean BMSLSS, $u_{0}$ & .01 & 37 & 41.16 & .29 & \\
\hline Victimization, $u_{2}$ & .09 & 37 & 69.34 & .00 & \\
\hline Level-1 effect, $r_{i j}$ & 1.94 & & & & \\
\hline
\end{tabular}

$* * * p<.001 ; * * p<.05 ; * p<.10$ 
For instance, Lawler et al. (2017) examined different predictors of well-being in the USA and ten other countries across different continents, including Chile. They found that relational, school, and community variables were significant predictors of SWB for children aged 10years old. Similarly, Zullig et al. (2018) report that school climate is important for, and contributes to students' overall school satisfaction. Owing to the finding in the current study that school climate perceptions were higher among girls in South Africa, it is argued that discrepancies in school climate can enforce broader consequences for males and females; this warrants further investigation. They also found that positive school climate and increased school satisfaction can be cultivated by interpersonal relationships that are characterized by feeling, being: respected, supported, and constructively challenged. In this regard, the consideration of Zullig et al. (2018) conceptual model that includes the reciprocal relations between 'school satisfaction', 'school climate', 'positive student engagement' and 'academic achievement' (adapted from Evans 1994, model of quality of life) would be useful.

Table 6 Results from the Between-school model of BMSLSS for South Africa

\begin{tabular}{|c|c|c|c|c|c|}
\hline Fixed effect & Coefficient & $S E$ & $t$ & $d f$ & $p$ \\
\hline \multicolumn{6}{|l|}{ School mean BMSLSS } \\
\hline Base, $\gamma_{00}$ & $8.36^{* * * *}$ & .07 & 123.14 & 13 & .00 \\
\hline School Climate, $\gamma_{0 I}$ & $.13^{*}$ & .06 & 2.06 & 13 & .06 \\
\hline \multicolumn{6}{|l|}{ Gender (Female) } \\
\hline Base, $\gamma_{10}$ & .01 & .06 & .16 & 973 & .88 \\
\hline \multicolumn{6}{|l|}{ Victimization, } \\
\hline Base, $\gamma_{20}$ & $-.49 * * *$ & .06 & -8.26 & 13 & .00 \\
\hline School Climate, $\gamma_{2 I}$ & .10 & .08 & 1.25 & 13 & .24 \\
\hline Random effect & Variance component & $d f$ & $\chi^{2}$ & $p$ & \\
\hline Mean BMSLSS, $u_{0}$ & .05 & 13 & 34.98 & .00 & \\
\hline Victimization, $u_{2}$ & .03 & 13 & 29.29 & .01 & \\
\hline Level-1 effect, $r_{i j}$ & 1.84 & & & & \\
\hline
\end{tabular}

$* * * p<.001 ; * * p<.05 ; * p<.10$ 


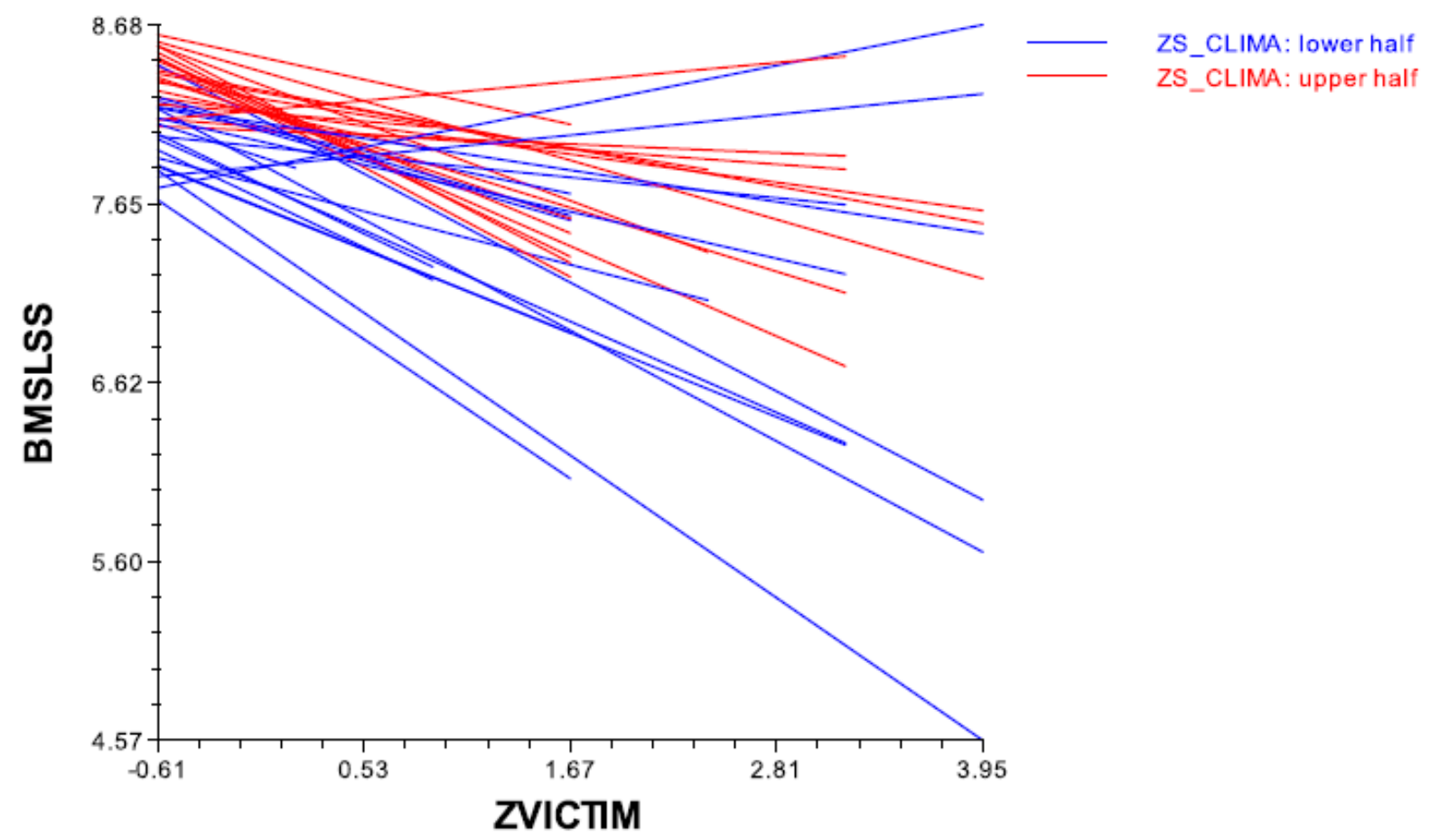

Fig. 1 Cross-level Interaction on the Relationship Between Victimization on BMSLSS based on School Climate. Note. ZVICTIM: Victim of bullying behavior; BMSLSS: Brief Multidimensional Students' Life Satisfaction Scale; ZS_Clima: School Climate

Table 7 Structural component for mediational model for Chile

\begin{tabular}{|c|c|c|c|c|c|}
\hline Outcome: & $R^{2}$ & Predictor & Direct effect & Indirect effect & Total effect \\
\hline School climate & .03 & Victimization & $-.18 * * *$ & & \\
\hline \multirow[t]{3}{*}{ BMSLSS } & .62 & Victimization & $-.28 * * *$ & $-.12 * * *$ & $-.40 * * *$ \\
\hline & & School Climate & $.68^{* * *}$ & & \\
\hline & & Gender & $-.08 *$ & & \\
\hline \multirow[t]{4}{*}{ Fit } & & Chi-square(df) & $1763.83(66)$ & & \\
\hline & & CFI & .93 & & \\
\hline & & TLI & .90 & & \\
\hline & & RMSEA & .06 & & \\
\hline
\end{tabular}

$* p<.05, * * p<.01, * * * p<.001$. Standardized coefficients are reported 
In the current study a cross level interaction was found between school climate and bullying victimization on children's SWB for the Chilean sample. This result highlights the role that can play school climate as a protective factor in the Chilean context, which is consistent with recent national reforms. In particular, Chile has developed national indicators of different indicators of quality, in addition to achievement. Among the indicators assessed is school climate, which is recorded each year across all schools in the country (Ministerio de Educación 2014). As it is exigent to protect children and adolescents from, and prevent, bullying at school it is imperative for collaboration and dialogue between schools, families, and communities, and to explore students' perceptions on the measurement of bullying (Roh 2015).

Finally, some limitations of the study should be noted. Although validated measures were employed in both countries, the sampling procedure was not the same in Chile and South Africa. Therefore, this should be considered particularly if attempting to generalize the results for the whole country. However, a strong feature of the study was the use of the same survey and measures (adapted appropriately) in both contexts. A second limitation to consider is the transversal nature of the data collected at one time point only. This can limit the data analysis when determining the established relationships among the study variables. Despite this, the model fit for the data still provides and informs meaningful results. Future studies can address this concern by collecting data at different time points, using a longitudinal design. A third limitation is that the assessment of bullying victimization only included two items, as this can limit our understating of bullying behavior. Future studies should examine the use of multi-item measures of bullying victimization, including different types of violent behavior.

Table 8 Structural component for mediational model for South Africa

\begin{tabular}{|c|c|c|c|c|c|}
\hline Outcome: & $R^{2}$ & Predictor & Direct effect & Indirect effect & Total effect \\
\hline School climate & .17 & Victimization & $-.41^{* * * *}$ & & \\
\hline \multirow[t]{3}{*}{ BMSLSS } & .62 & Victimization & $-.53^{* * * *}$ & $-.17 * * *$ & $-.70^{* * *}$ \\
\hline & & School Climate & $.41^{* * * *}$ & & \\
\hline & & Gender & -.01 & & \\
\hline \multirow[t]{4}{*}{ Fit } & & Chi-square(df) & $1310.61(66)$ & & \\
\hline & & CFI & .93 & & \\
\hline & & TLI & .91 & & \\
\hline & & RMSEA & .04 & & \\
\hline
\end{tabular}

${ }^{*} p<.05,{ }^{* *} p<.01,{ }^{*} * * p<.001$. Standardized coefficients are reported 
Chile

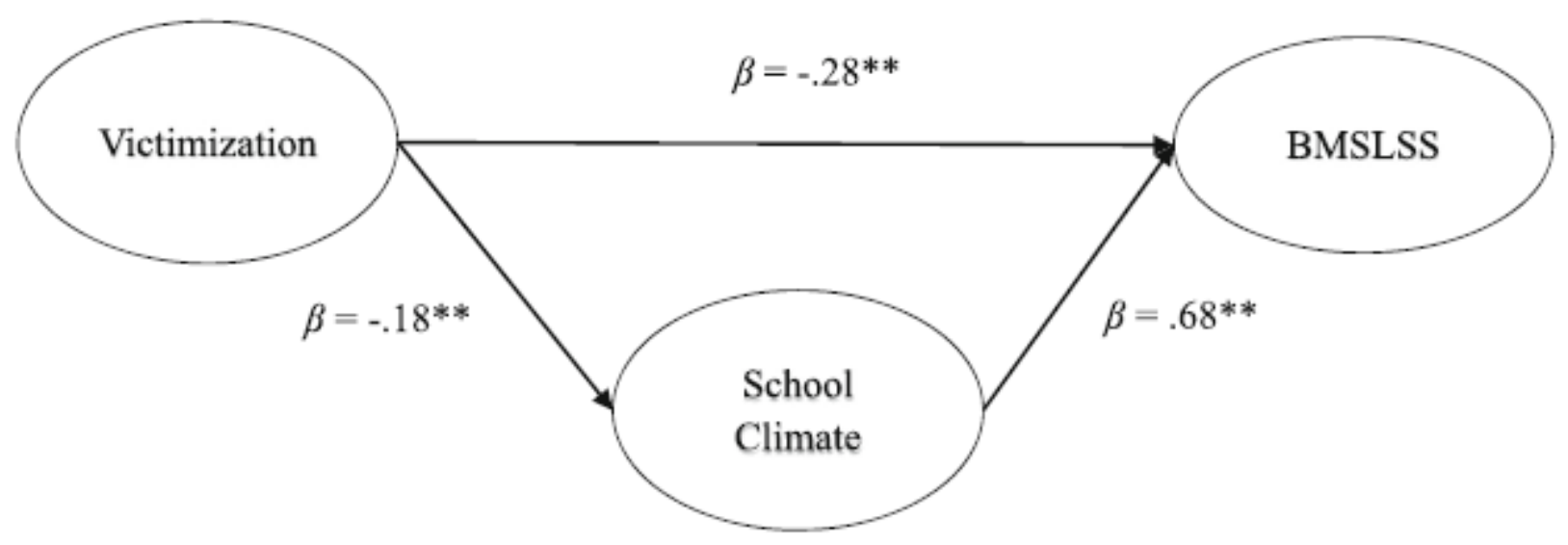

\section{South Africa}

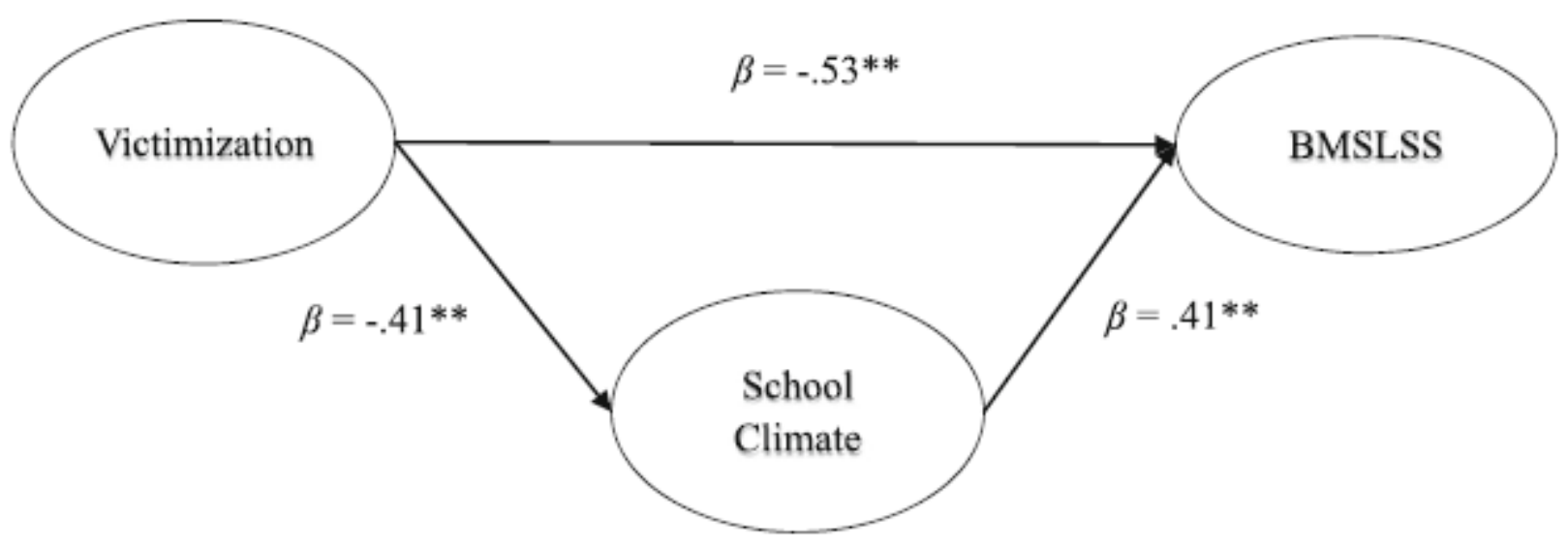

Note. ${ }^{*} p<.05, * * p<.01,{ }^{* * *} p<.001$. Standardized coefficients are reported

Fig. 2 Structural Equation Modeling for Chile and South Africa Results. Note. ${ }^{*} \mathrm{p}<.05,{ }^{* *} \mathrm{p}$ $<.01,{ }^{* * *} \mathrm{p}<.001$. Standardized coefficients are reported.

While the current study did not examine other demographic variables, such as gender, ethnicity, and SES, it is recommended that future studies explore the influence of these constructs on bullying victimization and SWB within the school climate. As gender was included as a control variable in the study, further exploration of this would be interesting considering the for a further focus on gender and children's SWB (see e.g. González-Carrasco et al. 2017). As noted by scholars in the field (Due et al. 2009), bullying is influenced by levels of inequality as assessed by the Gini coefficient. Therefore, within the South African context it would be important to consider this variable in future cross-country comparative studies, particularly given the lack of research in developing nations. While there are clear distinctions in terms of higher threats to safety and levels of violence against children in South Africa, in comparison to Chile, the countries face similar struggles, particularly in 
terms of child violence and inequality (UNICEF 2017). Moreover, given the levels of violence against children in South Africa and Chile (UNICEF 2017), appended to the risk of higher internalizing (trauma, social isolation, depression, anxiety, self-harm, and suicide) and externalizing (violent behavior, and bullying) problems related to increased bullying in these countries, this is cause for concern for children's well-being trajectories. Therefore, in the development of bullying prevention programmes, and in the development of policy, attention should be given to the reduction of deprivation and inequality as well as bullying. This underscores, and would contribute to addressing, the concern in countries where child deprivation is low and increased levels of inequality, which could afford a reduction in bullying in turn (Bradshaw and Rees 2017). Fostering a culture of relational well-being at school, that is advanced by positive relations within the family, and a safe community would further contribute to school satisfaction and an overall positive school experience and higher levels of SWB.

Despite the noted limitations, the study contributes to the literature by confirming a significant relationship between bullying victimization and SWB, and the inclusion of one feature from the school context such as school climate, to better understand this relationship. Given the wealth of knowledge on the crucial role of school context and satisfaction in shaping children's lives in other contexts, it is crucial that this is further examined within Chile and South Africa, and other developing contexts. Further, the study adds to the crosscultural comparative literature on children's SWB across two different cultural contexts, namely Chile and South Africa. Education should contribute to overall quality of life, thus highlighting the significance of focusing on and collecting consistent data and measurement of children's subjective perceptions of the school context and school and life satisfaction to identify the mechanisms through which to enhance this across populations and transcending geographical contexts (Zullig et al. 2009). As Noddings (2003) notes, happiness should be a key premise for every school, that can inform broader group as well as individual interventions within the school context.

\section{Compliance with Ethical Standards}

Conflict of Interest The authors declare that they have no conflict of interest.

\section{References}


Abubakr, A., van de Vijver, F., Alonso-Arbiol, I., et al. (2016). Measurement invariance of the brief multidimensional Student's life satisfaction scale among adolescents and emerging adults across 23 cultural contexts. Journal of Psychoeducational Assessment, 34(1), 28-38.

Aldridge, J. M., \& McChesney, K. (2018). The relationships between school climate and adolescent mental health and wellbeing: A systematic literature review. International Journal of Educational Research, 88(September 2017), 121-145. https://doi.org/10.1016/j.ijer.2018.01.012.

Alfaro, J., Guzmán, J., García, C., Sirlopú, D., Reyes, F., \& Varela, J. (2016). Psychometric properties of the Spanish version of the personal wellbeing index-school children (PWI-SC) in Chilean school children. Child Indicators Research, 9(3), 731-742. https://doi.org/10.1007/s12187-015-9342-2.

Ben-Arieh, A., Kaufman, H. N., Andrews, B. A., Goerge, R., Lee, B. J., \& Aber, J. L. (2001). Measuring and monitoring children's well-being. Dordrecht: Kluwer.

Berger, C. (2012). Trayectorias de victimización escolar: características y factores de riesgo en adolescentes chilenos. Universitas Psychologica, 11(1), 103-118.

Bonell, C., Allen, E.,Warren, E., McGowan, J., Bevilacqua, L., Jamal, F., Legood, R., Wiggins, M., Opondo, C., Mathiot, A., Sturgess, J., Fletcher, A., Sadique, Z., Elbourne, D., Christie, D., Bond, L., Scott, S., \& Viner, R. M. (2018). Effects of the learning together intervention on bullying and aggression in English secondary schools (INCLUSIVE): A cluster randomised controlled trial. The Lancet, 392(10163), 2452-2464. https://doi.org/10.1016/So140-6736(18)31782-3.

Bradshaw, J., \& Mayhew, E. (2005). The well-being of children in the UK. London: Save the children.

Bradshaw, J., \& Rees, G. (2017). Exploring national variations in child subjective well-being. Children and Youth Services Review, 80, 3-14. https://doi.org/10.1016/j.childyouth.2017.06.059.

Bradshaw, J., Martorano, B., Natali, L., \& de Neubourg, C. (2013). Children's subjective wellbeing in rich countries. Child Indicators Research, 6(4), 619-635. https://doi.org/10.1007/s12187-013-9196-4.

Casas, F. (2011). Subjective social indicators and child and adolescent well-being. Child Indicators Research, 4, 555-575.

Casas, F., \& Bello, A. (2012). Calidad de vida y bienestar subjetivo infantil en España. ¿Qué afecta al bienestar de niños y niñas de $1^{\circ}$ de ESO? España: UNICEF. Retrieved from https://www.unicef.es/sites/www.unicef.es/files/Bienestar_infantil_subjetivo_en_E spakua.pdf. Accessed Jan 2019.

Casas, F., \& González, M. (2017). School: One world or two worlds? Children's perspectives. Children and Youth Services Review, 80, 157-170.

Casas, F., González, M., Navarro, D., \& Aligué, M. (2013). Children as advisers of their researchers: Assuming a different status for children. Child Indicators Research, 6(2), 193-212. https://doi.org/10.1007/s12187-012-9168-o.

Catalano, R. F., Haggerty, K. P., Oesterle, S., Fleming, C. B., \& Hawkins, J. D. (2004). 
Findings from the social development research group. Journal of School Health, 74(7), 252-261.

Cohen, J., Mccabe, E. M., \& Michelli, N. M. (2009). School climate: Research, policy, practice, and teacher education. Teachers College Record, 111(1), 180-213.

Craig, W., Harel-Fisch, Y., Fogel-Grinvald, H., Dostaler, S., Hetland, J., Simons-Morton, B., et al. (2009). A cross-national profile of bullying and victimization among adolescents in 40 countries. International Journal of Public Health, 54(Suppl 2), 216-224. https://doi.org/10.1007/sooo38-009-5413-9.

Currie, C., Roberts, C., Morgan, A., Smith, R., Settertobulte, W., Samdal, O., \& Barnakov Rasmussen, V. (2004). Young people's health in context. C. Currie (Ed.).World Health Organization Regional Office for Europe.

Department of Basic Education. (2018). School realities 2017. https://www.education.gov.za/Portals/o/Documents/Reports/School\%2oRealities\% 202017.pdf Accessed 2 March 2018.

Diener, E. (2012). New findings and future directions for subjective well-being research. American Psychologist, 67, 590-597.

Diener, E., Suh, E. M., Lucas, R. E., \& Smith, H. L. (1999). Subjective well-being: Three decades of progress. Psychological Bulletin, 125, 276-302.

Dinisman, T., \& Ben-Arieh, A. (2015). The characteristics of Children's subjective well-being. Social Indicators Research, 126(2), 555-569. https://doi.org/10.1007/s11205-015-0921-x.

Due, P., Holstein, B. E., Lynch, J., Diderichsen, F., Gabhain, S. N., Scheidt, P., \& Currie, C. (2005). Bullying and symptoms among school-aged children: International comparative cross sectional study in 28 countries. European Journal of Public Health, 15, 128-132. https://doi.org/10.1093/eurpub/cki105.

Due, P., Merlo, J., Harel-Fisch, Y., Damsgaard, M. T., Holstein, B. E., et al. (2009). Socioeconomic inequality in exposure to bullying during adolescence: A comparative, cross-sectional, multilevel study in 35 countries. American Journal of Public Health, 99(5), 907-914.

Eccles, J. S., \& Roeser, R.W. (2010). An ecological view of schools and development. In J. L. Meece \& J. S. Eccles (Eds.), Handbook of research on schools, schooling, and human development (pp. 6-21). New York: Routledge.

Elgar, F. J., Craig, W., Boyce, W., Morgan, A., \& Vella-Zarb, R. (2009). Income inequality and school bullying: Multilevel study of adolescents in 37 countries. Journal of Adolescent Health, 45, 351-359. https://doi.org/10.1016/j.jadohealth.2009.04.004.

Elvas, S., \& Moniz, M. J. V. (2010). Sentimento de comunidade, qualidade e satisfação de vida. Análise Psicológica, 28(3), 451-464.

Espelage, D. L., \& De La Rue, L. (2012). School bullying: Its nature and ecology. International Journal of Adolescent Medicine and Health, 24(1), 3-10. https://doi.org/10.1515/ijamh.2012.002.

Fattore, T.,Mason, J., \&Watson, E. (2012). Locating the child centrally as subject in research: Towards a child interpretation of well-being. Child Indicators Research, 5(3), 423435. https://doi.org/10.1007/s12187-012-9150-x.

Felix, E. D., Furlong, M. J., \& Austin, G. (2009). A cluster analytic investigation of school 
violence victimization among diverse students. Journal of Interpersonal Violence, 24(10), 1673-1695. https://doi.org/10.1177/0886260509331507.

Fleming, C. B., Catalano, R. F., Haggerty, K. P., \& Abbott, R. D. (2010). Relationships between level and change in family, school, and peer factors during two periods of adolescence and problem behavior at age 19. Journal of Youth and Adolescence, 39(6), 670-682. https://doi.org/10.1007/s10964-010-9526-5.

Frey, A., Ruchkin, V., Martin, A., \& Schwab-Stone, M. (2009). Adolescents in transition: School and family characteristics in the development of violent behaviors entering high school. Child Psychiatry and Human Development, 40(1), 1-13. https://doi.org/10.1007/s10578-008-0105-x.

Gage, N. A., Prykanowski, D. A., \& Larson, A. (2014). School climate and bullying victimization: A latent class growth model analysis. School Psychology Quarterly, 29(3), 256-271. https://doi.org/10.1037/spq0000064.

González-Carrasco, M., Casas, F., Malo, S., Viñas, F., \& Dinisman, T. (2017). Changes with age in subjective well-being through the adolescent years: Differences by gender. Journal of Happiness Studies, 18(1), 63-88. https://doi.org/10.1007/s10902-016-9717-1.

González-Carrasco, M., Casas, F., Ben-Arieh, A., Savahl, S., \& Tiliouine, H. (2018). Children's perspectives and evaluations of safety in diverse settings and their subjective wellbeing: A multi-National Approach. Applied Research in Quality of Life. https://doi.org/10.1007/s11482-018-9594-3.

Goswami, H. (2013). Children's subjective well-being: Socio-demographic characteristics and personality. Child Indicators Research, 7(1), 119-140. https://doi.org/10.1007/s12187-013-9205-7.

Hashim, J., \& Areepattamannil, S. (2017). The brief multidimensional Students' life satisfaction scale (BMSLSS): Reliability, validity, and gender invariance in an Indian adolescent sample. Journal of Adolescence, 57, 54-58.

Henry, D. B., Tolan, P. H., Gorman-Smith, D., \& Schoeny, M. E. (2012). Risk and direct protective factors for youth violence: Results from the Centers for Disease Control and Prevention's multisite violence prevention project. American Journal of Preventive Medicine, 43(2 Suppl 1), S67-S75. https://doi.org/10.1016/j.amepre.2012.04.025.

Huebner, E. S. (2004). Research on assessment of life satisfaction of children and adolescents. Social Indicators Research, 66(1-2), 3-33.

Huebner, E. S., Suldo, S.M., Smith, L. C., \& McKnight, C. G. (2004). Life satisfaction in children and youth:

Empirical foundations and implications for school psychologists. Psychology in the Schools, 41(1), 81-93. https://doi.org/10.1002/pits.10140.

Huebner, E. S., Hills, K., Jiang, X., Long, R., Kelly, R., \& Lyons, M. (2014). Schooling and children's subjective well-being. In A. Ben-Arieh, F. Casas, I. Frønes, \& J. E. Korbin (Eds.), Handbook of child well-being (pp. 797-819). Dordrecht: Springer. https://doi.org/10.1007/978-90-481-9063-8_26.

Instituto Nacional de la Juventud. (2017). Sondeo $\mathrm{N}^{\circ} 5$ : Bullying en establecimientos educacionales. Jóvenes entre 15 y 29 años. Santiago: Dirección de Estudios Sociales. Ito, A., \& Smith, D. C. (2006). Predictors of school satisfaction among Japanese and US 
youth. The Community Psychologist, 38(4), 19-21.

Jutras, S., \& Lepage, G. (2006). Parental perceptions of contributions of school and neighborhood to children's psychological wellness. Journal of Community Psychology, 34(3), 305-325. https://doi.org/10.1002/jcop.20101.

Klein, J., Cornell, D., \& Konold, T. (2012). Relationships between bullying, school climate, and student risk behaviors. School Psychology Quarterly, 27(3), 154-169. https://doi.org/10.1037/aoo29350.

Kutsyuruba, B., Klinger, D. A., \& Hussain, A. (2015). Relationships among school climate, school safety, and student achievement and well-being: A review of the literature. The Review of Education, 3(2), 136-137. https://doi.org/10.1002/rev3.3045.

Låftman, S. B., Östberg, V., \&Modin, B. (2017). School climate and exposure to bullying: A multilevel study. School Effectiveness and School Improvement, 28(1), 153-164. https://doi.org/10.1080/09243453.2016.1253591.

Lawler, M., Lewland, L. A., Giger, J. T., Roth, S., \& Brockevelt, B. (2017). Ecological,relationship-based model of children's subjective well-being: Perspectives of 10-year-old children in the United States and 10 other countries. Child Indicators Research, 10(1), 1-18. https://doi.org/10.1007/s12187-016-9376-o.

Lerner, R. M. (2006). Developmental science, developmental systems, and contemporary theories of human development. In R. A. Lerner (Ed.), Handbook of child psychology: Vol. 1, Theoretical models of human development (6th ed., pp. 1-17). Hoboken: Wiley.

Loukas, A., \& Murphy, J. L. (2007). Middle school student perceptions of school climate: Examining protective functions on subsequent adjustment problems. Journal of School Psychology, 45(3), 293-309. https://doi.org/10.1016/j.jsp.2006.10.001.

MacDonald, J. M., Piquero, A. R., Valois, R. F., \& Zullig, K. J. (2005). The relationship between life satisfaction, risk-taking behaviors, and youth violence. Journal of Interpersonal Violence, 20(11), 1495-1518. https://doi.org/10.1177/0886260505278718.

Magendzo, A., Toledo, M. I., \& Gutiérrez, V. (2012). Descripción y análisis de la Ley sobre Violencia Escolar ( $\mathrm{N}^{\circ}$ 20.536): dos paradigmas antagónicos. Estudios Pedagógicos, 39(1), 377-391. https://doi.org/10.4067/So718-07052013000100022.

Martin, K. M., \& Huebner, E. (2007). Peer victimization and prosocial experiences and emotional well-being of middle school students. Psychology in the schools. Psychology in the Schools, 44(2), 199-208. https://doi.org/10.1002/pits.20216.

Mathews, S., \& Benvenuti, P. (2014). Violence against children in South Africa: Developing a prevention agenda (Part Two). In S. Mathews, L. Jamieson, \& C. Smith (Eds.), South African Child 2014. University of Cape Town: Children's Institute.

McDougall, J., Wright, V., Nicols, M., \& Miller, L. (2013). Assessing the psychometric properties of both a global and a domain-specific perceived quality of life measure when used with youth who have chronic Conditions. Social Indicators Research, 114, 1243-1257. https://doi.org/10.1007/s11205-012-0200-z.

McNeely, C., \& Falci, C. (2004). School connectedness and the transition into and out of health-risk behaviour among adolescents: A comparison of social belonging and teacher support. Journal of School Health, 74(7), 284-292. https://doi.org/10.1111/j.1746-1561.2004.tbo8285.x. 
Mehta, S., Cornell, D. G., \& Konold, T. R. (2009). Validity of three school climate scales to assess bullying, aggressive attitudes, and help seeking. School Psychology Review, 38(3), 338-341.

Menesini, E., \& Salmivalli, C. (2017). Bullying in schools: The state of knowledge and effective interventions. Psychology, Health \& Medicine, 22, 240-253. https://doi.org/10.1080/13548506.2017.1279740.

Migliorini, L., Tassara, T., \& Rania, N. (2019). A study of subjective well-being and life satisfaction in Italy: How are children doing at 8 years of age? Child Indicators Research, 12, 49-69. https://doi.org/10.1007/s12187-017-9514-3.

MINEDUC, Centro de Estudios, Ministerio de Educación. (2017). Estadísticas de la Educación 2016. Santiago: Centro de estudio MINEDUC y División de Planificación y Presupuesto.

Ministerio de Educación. (2011). Encuesta nacional prevención, agresión y acoso escolar 2011. Santiago: Autor.

Ministerio de Educación. (2014). Fundamentos: otros indicadores de calidad educativa. Santiago: Ministerio de Educación. Unidad de Currículum y Evaluación https://is.gd/gTaMl6. Accessed 12 March 2018.

Ministerio del Interior. (2014). Cuarta Encuesta Nacional de Violencia en el Ámbito Escolar 2014. Santiago: Autor.

Ministerio del Interior \& Adimark GFK. (2008). Encuesta de Violencia en el Ámbito Escolar 2005-2007. Santiago: Autor.

Ministerio del Interior \& Adimark GFK. (2010). Tercera Encuesta Nacional de Violencia en el Ámbito Escolar 2009. Santiago: Autor.

Molcho, M., Craig, W., Due, P., Pickett, W., Harel-Fisch, Y., Overpeck, M., ... Wang, J. (2009). Crossnational time trends in bullying behaviour 1994 - 2006: Findings from Europe and North America. International Journal of Public Health, 54, 225-234. https://doi.org/10.1007/s00038-009-5414-8.

Muñoz-Reyes, J. A., Polo, P., Valenzuela, N., Guerra, R., Anabalón, K., Hidalgo-Rasmussen, C., \& Turiégano, E. (2016). Sexual differences and associations between aggressiveness and quality of life in late adolescents. Current Psychology, 37, 1-10. https://doi.org/10.1007/s12144-016-9486-3.

Newland, L. A., Giger, J. T., Lawler, M. J., Roh, S., Brockevelt, B. L., \& Schweinle, A. (2019). Multilevel analysis of child and adolescent subjective well-being across 14 countries: Child-and country-level predictors. Child Development, 90(2), 395-413. https://doi.org/10.1111/cdev.13134.

Ng, Z. J., Huebner, E. S., Maydeu-Olivares, A., \& Hills, K. J. (2017). Confirmatory factor analytic structure and measurement invariance of the brief multidimensional students' life satisfaction scale (BMSLSS) in a longitudinal sample of adolescents. Child Indicators Research, 11, 1237-1247. https://doi.org/10.1007/s12187-017-946.

Noddings, N. (2003). Happiness and education. New York: Cambridge University Press. Norman, R., Schneider, M., Bradshaw, D., Jewkes, R., Abrahams, N., Matzopoulos, R., \& 
Vos, T. (2010). Interpersonal violence: An important risk factor for disease and injury in South Africa. Population Health Metrics, 8(32), 1-12.

https://doi.org/10.1186/1478-7954-8-32.

OECD. (2015). Education at a Glance: OECD Indicators 2015. Country note. Paris: Author. https://doi.org/10.1787/eag-2015-en.

OECD. (2017), PISA 2015 Results (Volume III): Students' Well-Being, PISA, OECD Publishing, Paris. https://doi.org/10.1787/9789264273856-en.

Olweus, D. (1978). Aggression in the schools: Bullies and whipping boys. Oxford: Hemisphere.

Olweus, D., \& Breivik, K. (2014). Plight of victims of school bullying: The opposite of wellbeing. In A. Ben-Arieh, F. Casas, I. Frønes, \& J. E. Korbin (Eds.), Handbook of child well-being (pp. 2593-2616). Dordrecht: Springer. https://doi.org/10.1007/978-90-481-9063-8_100.

Oyanedel, J. C., Alfaro, J., Varela, J., \& Torres, J. (2014). Resultados de la Encuesta Internacional sobre bienestar subjetivo infantil. http://www.isciweb.org/_Uploads/dbsAttachedFiles/ISCWeBChile_2014.pdf. Accessed 30 March 2018.

Pizmony-Levy, O., \& Kosciw, J. G. (2016). School climate and the experience of LGBT students: A comparison of the United States and Israel. Journal of LGBT Youth, 13(1), 46-66. https://doi.org/10.1080/19361653.2015.1108258.

Proctor, C. L., Linley, P. A., \& Maltby, J. (2009). Youth life satisfaction: A review of the literature. Journal of Happiness Studies, 10(5), 583-630. https://doi.org/10.1007/s10902-008-9110-9.

Raudenbush, S. W., \& Bryk, A. S. (2002). Hierarchical linear models: Applications and data analysis methods. London: Sage.

Rees, G., \& Main, G. (Eds.). (2015). Children's views on their lives and well-being in 15 countries: An initial report on the Children's Worlds survey, 2013-14. York: Children's Worlds Project (ISCWeB).

Rees, G., Goswami, H., Pople, L., Bradshaw, J., Keung, A., \& Main, G. (2012). The good childhood report 2012: A review of our children's well-being. http://www.childrenssociety.org.uk/sites/default/ Accessed 25 March 2018.

Richardson, D., \& Hiu, C. F. (2016). Ending the torment: Tackling bullying from the schoolyard to cyberspace, office of the special representative of the secretary-general on violence against children New York.

http://srsg.violenceagainstchildren.org/sites/default/files/2016/End\%2obullying/bul lyingreport.pdf Accessed 12 March 2018.

Roh, et al. (2015). The structure of co-occurring bullying experiences and associations with suicidal behaviors in Korean adolescents. PLoS One, 10(11), e0143517.

https://doi.org/10.1371/journal.pone.0143517.

Rudasill, K. M., Snyder, K. E., Levinson, H., \& L. Adelson, J. (2018). Systems view of school climate: A theoretical framework for research. Educational Psychology Review, 30(1), 35-6o. https://doi.org/10.1007/s10648-017-9401-y.

Samdal, O., Dur, W., \& Freeman, J. (2004). Life circumstances of young people - school. 
Young people's health in context. Health behaviour in school-aged children (HBSC) study: International report of the 2001/02 survey, 42-51.

Sarriera, J., Friedrich, F., Galli, F., Bedin, L., Wachholz, R., \& Zanatta, T. (2014). Bem-estar na infância e fatores psicossociais asociados. Porto Alegre: Universidade Federal do Rio Grande do Sul.

Savahl, S., Malcolm, C., Slembrouk, S., Adams, S., Willenberg, I., \& September, R. (2015). Discourses on well-being. Child Indicators Research, 8(4), 747-766.

Savahl, S., Tiliouine, H., Casas, F., Adams, S., Mekonen, Y., M., Dejene, N., Benninger, E., \& Witten, H. (2017). Subjective well-being across three African countries: A comparative study. Children and Youth Services Review, 80, 31-40.

Savahl, S.,Montserrat, C., Casas, F., Adams, S., Tiliouine, H., Benninger, E., \& Jackson, K. (2018). Children's experiences of bullying victimization and the impact on their subjective well-being: A multinational comparison. Child Development, 90(2), 414431. https://doi.org/10.1111/cdev.13135.

Schütz, F. F., Bedin, L. M., \& Sarriera, J. C. (2018). Subjective well-being of Brazilian children from different family settings. Applied Research in Quality of Life. https://doi.org/10.1007/s11482-018-9609-0.

Seligson, J. L., Huebner, E. S., \& Valois, R. F. (2003). Preliminary validation of the brief multidimensional students' life satisfaction scale (BMSLSS). Social Indicators Research, 61(2), 121-145. https://doi.org/10.1023/A:1021326822957.

Shek, D. T. L., \& Liang, L. (2018). Psychosocial factors influencing individual well-being in Chinese adolescents in Hong Kong: A six-year longitudinal study. Applied Research in Quality of Life, 13(3), 561-584. https://doi.org/10.1007/s11482-017-9545-4.

Strozik, D., Strozik, T., \& Szwarc, K. (2016). The subjective well-being of school children. The first findings from the Children's worlds study in Poland. Child Indicators Research, 9, 39-50. https://doi.org/10.1007/s12187-015-9312-8.

Suldo, S.M., Shaffer, E. J., \& Riley, K. N. (2008). A social-cognitive-behavioral model of academic predictors of adolescents' life satisfaction. School Psychology Quarterly, 23(1), 56-69. https://doi.org/10.1037/1045-3830.23.1.56.

Tiliouine, H. (2015). School bullying victimisation and subjective well-being in Algeria. Child Indicators Research, 8(1), 133-150. https://doi.org/10.1007/s12187-014-9286-y.

Turner, I., Reynolds, K. J., Lee, E., Subasic, E., \& Bromhead, D. (2014). Well-being, school climate, and the social identity process: A latent growth model study of bullying perpetration and peer victimization.School Psychology Quarterly, 29(3), 320-335. https://doi.org/10.1037/spqooooo74.

UNICEF. (2013). Estado mundial de la infancia 2013: Niños y niñas con discapacidad. Nueva York: Autor https://www.unicef.org/spanish/publications/files/SPANISH_SOWC2013_Lo_res.p df. Accessed 25 May 2018.

UNICEF. (2017). Annual report 2017: Chile. New York: Author.

Valois, R. F., Paxton, R. J., Zullig, K. J., \& Huebner, E. S. (2006). Life satisfaction and violent Behaviors among middle school students. Journal of Child and Family Studies, 15(6), 695-707. https://doi.org/10.1007/s10826-006-9043-z.

Varela, J. (2011). Efectividad de Estrategias de Prevención de Violencia Escolar: La 
Experiencia del Programa Recoleta en Buena. Psykhe, 20(2), 65-78. https://doi.org/10.1163/_q3_SIM_o0374.

Varela, J., Schwaderer, H., Cárcamo, J., \& Oyanedel, J. (2012). Acoso escolar cibernético (ciberbullying) y violencia en el contexto escolar: chay una relación entre ambos tipos de victimización? En VII Congreso Nacional de Investigación sobre Violencia y Delincuencia, Santiago, 28-29 Septiembre 2011. Santiago, Chile. pp. 93-108.

Varela, J. J., Zimmerman, M. A., Ryan, A. M., Stoddard, S. A., Heinze, J. E., \& Alfaro, J. (2017). Life satisfaction, school satisfaction, and school violence: A mediation analysis for Chilean adolescent victims and perpetrators. Child Indicators Research, 11(2), 487-505. https://doi.org/10.1007/s12187-016-9442-7.

Wang, C., Berry, B., \& Swearer, S. M. (2013). The critical role of school climate in effective bullying prevention. Theory Into Practice, 52(4), 296-302. https://doi.org/10.1080/00405841.2013.829735.

Yang, C., Bear, G. G., Chen, F. F., Zhang, W., Blank, J. C., \& Huang, X. (2013). Students' perceptions of school climate in the U.S. and China. School Psychology Quarterly, 28(1), 7-24. https://doi.org/10.1037/spq0000002.

Zullig, K. J., Koopman, T. M., \& Huebner, E. S. (2009). Beyond GPA: Toward more comprehensive assessments of students' school experiences. Child Indicators Research, 2(1), 95-108. https://doi.org/10.1007/s12187-008-9029-z.

Zullig, K. J., Ward, R. M., Huebner, S. E., \& Daily, S. M. (2018). Association between adolescent school climate and perceived quality of life. Child Indicators Research, 11(6), 1737-1753. https://doi.org/10.1007/s12187-017-9521-4. 